\title{
The Failure of Indonesian Integration in the Reform Era: a Case of Semarang's Chinese Community
}

\author{
Zeffry Alkatiri ${ }^{1}$, Vincentia Irmayanti ${ }^{2}, \&$ Adrianus LG Waworuntu ${ }^{2}$ \\ ${ }^{1}$ Lecturer and Researcher at the History Department of the Faculty of Humanities, University of Indonesia, Indonesia. \\ ${ }^{2}$ Lecturer and Researcher at the Regional Studies Department, University of Indonesia, Indonesia. \\ Correspondence: Zeffry Alkatiri, Lecturer and Researcher at the History Department of the Faculty of Humanities, \\ University of Indonesia, Indonesia.
}

Received: January 5, 2015

Accepted: January 22, 2015

Available online: February 25, 2015

doi:10.11114/ijsss.v3i2.630

URL: http://dx.doi.org/10.11114/ijsss.v3i2.630

\begin{abstract}
This article delves into the failure potentials of Indonesian integration in social and cultural interaction pattern of the Javanese-Chinese in Semarang's Chinatown in Reform Era. This article is a pilot project to look into social and cultural interaction pattern toward Indonesia's integration post New Order Era (or Reform era). It was long recorded that the Chinese communities have interacted with the locals for several generations so it has created a pattern of social and cultural mix between the Chinese-descent communities in Semarang with the local Javanese culture. This article uses both data gathered from the field and from library research. It utilizes ethnographic method approach putting the emphasis on diverse actions in their social and cultural interaction pattern. This paper is expected to be used as an example of national integration efforts failed in some of Indonesia's diverse communities and showed the tensions between minority and majority communities or between Islam and not Islam in other areas in Indonesia.
\end{abstract}

Keywords: Indonesian integration, Chinese-Javanese, Semarang's, Reform Era

\section{Introduction}

Integration issue in multicultural society like Indonesia is a complex and crucial and is the main focus in the process of creating a unity of the diverse Indonesia. Up to now, there are a number of problems relating to integration taking place since the Independence which have yet been settled. One of the problems is the issue of minority community, especially the Chinese community, which is basically different religion-wise and culture-wise from the majority local community. This in turn has triggered political instability during two administrations until now and becomes a burden for the government in achieving national integration in the diversity of the Indonesian people.

Historically, Semarang's Chinatown (Central Java) was shaped in such a natural way by the Chinese immigrants who gathered together and formed a housing area. However, in its later journey, this Chinatown was politically shaped by the VOC. Previously the Chinese immigrants were living separately in a number of places, but after the Chinese riot in Batavia in 1740 and the Chinese revolt occurred in a residency of the Mataram Kingdom, the Chinese communities who lived separately were united in one area by VOC which later and until now known as the Chinatown area, meaning the place where the Chinese immigrants reside (Joe, 2004:34, 56). After that, the life of the Chinese immigrants in Semarang and also in other big cities in Java, pretty much like the Ghetto which was guarded by the military who happened to be close to their headquarter. At Chinatown, on one side, they were able to develop their cultural identity, but on the other side, they had become closed and isolated from the surrounding communities. After that the colonial administration even issued other regulations, other than tax regulation, and that includes the obligation to have permits to go in and out of their house (Passenstelsel and Wijkenstelsel) and other permits such as renovating a building, how to wear clothes, and even establishing a school. They had lived this historical path in the hardest way, but they still have the energy to maintain their cultural identity showed in their use of language, their faith, their culture, their ability to build social and business network and passed on their custom and tradition from generation to generation (Ham, 2005 and 2008).

During the Soekarno era (1945-1966), the Chinese communities faced transition. On one side they had to choose their citizenship, but on the other side, they were not allowed to have business in rural areas. Despite the regulation, some influential Chinese figures were granted power in parliament and ministries. The Soekarno administration 
accommodated part of the Chinese identity in nationalism, as far as it was about economics and politics, whilst the social and cultural aspects had not been seriously thought about.

During the New Order (1968-1998) the life and culture of the Chinese people was completely banned. For 32 years this policy has cause a lost generation (the generation that lost their own cultural tradition), including what had taken place in Semarang's Chinatown. It had brought serious impact to the life of the Chinese community like they were gradually losing their family ties; they were confused of the name changing, faith changing, of disappearance of some elements of Chinese culture as shown in architecture and ash table. On the other side, interestingly, some business leaders of Chinese descent were protected by the military regime of the New Order and they acted as partner in the collaboration in the New Order Development machinery (Grief, 1991: 62).

However, entering the Reform era (1998-now), the hindrances created by the New Order regime for the Chinese community were cleared out. In Reform era, they started to enjoy better freedom to articulate their opinion through voting, or being voted in political field; there was even a leading figure who found a political party and mass organization. Their native language was widely uses once again and this had encouraged many Mandarin language courses and it was also taught in a number of private and public schools. Under Presidential Decision No. 14/2000 on the repeal the President Instruction No.14/1967 has helped the recognition of the identity and existence of the Chinese community in one multiculturalist vessel in Indonesia.The most significant recognition from the government for the Chinese minority was the acknowledgment of Chinese New Year as national holiday.

Despite the fact that opportunities have been opened, there are still hindrances that get in the way the process toward Indonesia's integration. Based on the issue, this article aims to delve into the failure of Indonesian integration in reform era, a case of interaction the Chinese-Javanese community at Semarang's Chinatown.

\section{Material Studied}

The issue of integration and assimilation between Chinese descent and the locals in Indonesia (Java) have already substantially discussed as a books or an articles. Generally the existing writings examine various factors that have hindered interaction between the two parties. The difficulties relating to actual differences like faith have been the main factor that got in the way of such interaction. The following are a number of studies which have been done before and they examine the issue of national integration, case studies interaction between the Chinese community and the locals.

A book titled Kultur Cina dan Jawa: Pemahaman Menuju Asimilasi Kultural (2004) is authored by P. Haryono. This book discusses the issue of assimilation between the Chinese and the locals, which in this case involves the Javanese community in Yogyakarta. This book focuses on how those two communities are able to assimilate with the help of cultural bridge. This book concludes that the assimilation process would happen properly if it involves two parties who need one another and mutually complete each other's life.

A book titled, Becoming Javanese: Chinese People and Javanese Culture in Surakarta 1895-1998 is written by Rustopo (2007). This book explores the process to shape the identity of being Javanese done by the Chinese community in Surakarta since the end of the $19^{\text {th }}$ century and throughout the $20^{\text {th }}$ century. This book places the Chinese, both as a community and as an individual, integrating to one Javanese community and culture. However, in social interaction there occurs often the issue of latent disparity and sometimes it triggered insurgencies. This book also reveals the opportunities and hindrances in cultural interaction between the Chinese who are able to blend into the values and the elements of Javanese culture.

An article written by Zeffry Alkatiri and Fabianus Koesoemadinata titled 'Plural Community-based Celebration Parade of Toa Pe Kong in Slawi Post New Order 2010' (in Jurnal Antropologi Indonesia, No.2, Vol.2, 2012, page: 43-58). This article reveals that some functions and meanings of the celebrations of New Year and Toa Pe Kong are positive since those celebrations have turned into a vessel of accommodation and competition of three different interests, which are political and economic interests and cultural expression. Barongsai performance has become an effective method for assimilation model between the Chinese descent-community and the locals. This shows that celebration using arts has the potential to become an arena for people from different faith and culture to meet.

A number of articles are taken from two books written by Ong Hok Ham, The Story of Chinese Descent in Java (2005) and Anti-China, China Capitalism and China Movement: The History of the Ethnic China in Indonesia (2008). In those articles he disclosed the history of the assimilation of the Chinese immigrants taking place in Indonesia. Since early $4^{\text {th }}$ century to the New Order era, the facts of history unfold that the interaction of the Chinese and the locals have occurred for centuries. Many elements of Chinese culture have blended with other elements. In its journey through time, the Dutch colonial grouped the Chinese into a component of foreigner coming from the East (Vreemde Oosterlingen). After the independence, Soekarno administration attempted to exercise assimilation policy. But, the assimilation to national integration process was something coercive because the government at that time saw the concept of assimilation also as 
Indonesianization. After the bloody incident of 30 September, in 1967 the New Order regime issued a Presidential Instruction No. 14/1967 that banned all the Chinese religion and custom-related celebrations. It can be concluded that for 32 years the identity of being Chinese has been something tabooed to show. However in Reformation era, many obstacles have been eliminated. After President Abdurrahman Wahid issued the Presidential Decree No.6/2000 on the annulment of the Presidential Instruction issued in 1967, the existence of the Chinese community has gained more recognition. The acknowledgment of their existence as part of the Indonesian people was confirmed by President Megawati by making Chinese New Year as national holiday.

Other reference is from Ahmad Habib with his book Interethnic Conflict in Rural Areas: The Ups and Downs of Chinese-Javanese Relation (2009). This book analysed the conflict between the Chinese and Javanese on a land in rural area in East Java. This conflict was a disagreement involving a very crucial land confiscation since the Independence Day until around 1980s. This conflict began to come about when the Chinese businessmen were able to work the land but they used closed system which pushed the local cultivators and settlers to be marginalized. On the one side, the arrival of Chinese businessmen has brought in financial benefit for the local settlers, but on the other side, they have marginalized the cultivators who at first have no ability to compete. This unhealthy competition has created social envy and has made the local farmers apprehensive. The result was that the farmers and cultivators tried to seize the land of the Chinese, both with physical force and in a subtle way. It is this lack of understanding and abuse of the Chinese as migrants that has brought in prolonged conflict.

Departing from the initial study, this article focuses on the studies of the failure of Indonesian integration in the reform era, case studies of interaction the Chinese community in certain local community, which is in Semarang's Chinatown. This article is a qualitative research. Data collected from various reference books, articles, and internet media associated with focus theme. Data collection was also done in the field by direct observation and assisted with interviews to a number of people associated with the theme. To deepen the focus of the study, conducted FGDs (focus group discussions), which involves 14 community leaders in Chinatown Semarang, such as journalists, observers Chinatown, academics, businessmen, art activists, board of trustees, members of Parliament, and the Head of Tourism Department of Semarang. While the theoretical approach is done through the study of the meaning enthnografi interaction actions undertaken by the Chinese community in Chinatown Semarang.

This article also uses the concept and theoretical framework relating to social and cultural interactions. Social interaction is a relationship between individuals or groups of individuals or other groups that are reciprocal. In the dynamics of the process of social interaction will be seen, such as (1) the existence of a relationship between individuals who have a particular interest, (2) a conflict, (3) there is a place to gather, (4) lack of awareness of individual or collective consciousness (Thohir, 2007: 2- 4). In this case it would seem that the actors have behaviors that show significant behavior (meaningfull action) or behaviors that are not meaningful (meaningless action) in contributing to their social action (Gidden and Jonathan Turner, 1988).

In a relationship that this article will look at what actions the Chinese community in Chinatown Semarang in interacting with local residents (Javanese) in today's era of reform leading to meaningfull action or otherwise (meaningless action) in order to raise cooperation to Indonesian society towards multicultural integration?

\section{Area Description}

'Pecinan' or in English they use the term 'Chinatown' originates from a Javanese language which means an area where the majority of its residents is Chinese descent. Besides serving as the centre of the Chinese descent residence, Pecinan was also a trading hub. In Southeast Asia they are also familiar with the term 'Chinatown'. Nearly every big city in Indonesia has this Chinatown area, which is also referred as "Kampung Cina" 'The Village of the Chinese'. The Chinatowns we know in Java can be found in Jakarta, Bandung, Semarang, Surabaya, Solo, and Malang, whilst for outside Java they can be found in Padang, Medan, Pontianak, Makassar, and Menado.

The houses inside the Chinatown generally comprise shop-houseconstruction and a Temple. The shop-houses along the Chinatown serve as business points and their houses. The constructions and houses in Chinatown area have specific features shown in their physical characteristics which are mostly two-storey buildings. The first floor is for the business whereas it's on the second floor that they build a dwelling place.

Semarang's Chinatown has gone through many ups and downs in the dynamics of the history of Semarang City. Initially the residential areas of the Chinese community in Semarang were located in Simongan area. In 1740 the Chinatown was moved to the western part of the Semarang River. The location of the Semarang's Chinatown was so close to the port, surrounded by the houses of the locals, and near the Semarang River which could be accessed using small boats as the mode of transportation at that time. This hustle and bustle of trading had granted the Chinese people their important role in Semarang's economy growth and it had made them a community with better life compared to that of the locals in Semarang. 
Chinatown was shaped based on two reasons: political and social reasons. The political reasons involved colonial government regulations that oblige the Chinese community to live concentrated in one area in order to make them easier to manage and control (Wijkenstelsel). This was a consequence of the segregation based on racial background. Moreover, they were required to have permits to go in and out the Chinatown, which was called travel permit or passenstelsel in Dutch language. Previously Chinatown was surrounded by walls separating their residential area from others like Pekojan Village (Arab Village) and several Indigenous Village, and the Dutch Residential. In terms of social grounds it was because of their own wish to live in groups in order to maintain their feeling of security and they were able to help each other. But, even this was quite normal and fair, it needs to bear in mind that other immigrants like the Indians, Arabs, and ethnics from across the nation, including the Dutch had built their own respective residential area. Chinatown was usually close to traditional market as market is where selling and buying everyday retail items takes place. Strategically Chinatown area also functions as buffer zone for the areas of the Europeans whenever there was an insurgence or resistance from the indigenous people against the Dutch (Joe, 2004: 24 and 31).

Such description at present on Semarang's Chinatown is actually a picture of the life of Chinese ethnic or community in Central Java who have gone through a long history, which also shows a social and cultural identity as a process to place itself and is placed by a power from the outside - in this case the other ethnics surrounding them, especially the Java ethnic and also the state.

There exists a special term for Chinese: Orang Babah (for Chinese peranakan) and Orang Totok (the Chinese who just came in). Orang Babah shows a mixed culture with Javanese people such as exercising selamatan 'ritual for safety purposes' and Javanese arts and cultural performance like Wayang Orang, Ketoprak and Karawitan. They then formed a social and cultural association. There are approximately dozens of Chinese community associations in Semarang. However, it's only Boen Hian Tong (a gathering place formed in 1876) who survived until now but it has changed its name into the association of Rasa Dharma. Whilst 'Cina Totok' is the Chinese community who are still closed or still keep their cultural tradition from mainland China; today there is no such community anymore. With the social and cultural integration between the Chinese and Javanese it shows that the Javanese custom and tradition has the ability to accept other culture and it includes the Chinese culture and tradition (Wargathjie, 2007: 8-26).

Generally speaking the residents of the Chinatown area can be divided into (1). Native residents who have long lived in the area since they were born and they house-shop in the area which they inherited from their ancestors, (2) Native residents who have lived in the Chinatown area since they were born, but they only used their house-shop as business point or storehouse; they didn't live in Chinatown area. It's just because their work happened to be in the area such labourers or non-permanent traders in the market.

Although most of today's Chinatown areas look like slums, not well maintained and dirty, the houses are so close one and another without yard, without plants, bad environment, frequently in undated, for some of the inhabitants, particularly the traders, considered this location as very strategic. Nearly all the needs of the inhabitants of Semarang could be fulfilled in Chinatown. Not all of the members of the Chinese community here are equally rich; some of them are poor. They live in huts on the banks of Koping River. They work as labours, beggars, and food sellers (Svarajati, 2013: 4-26).

\section{Methods and Technique}

This research using mixed method, methods ethnographi and in-depth interviews to informants from the city of Semarang. Also used method of interpretation, it is used to understand the results of interviews of informants. To support this research conducted FGD (Focus Group Discussion) between research teams with key informants and representatives of the Chinese community in Semarang.

\section{Results}

The process of integration in Chinesa community in the reform should pay attention to the presence of (a) the condition of the Chinese community in Indonesia as a country that has a plural society (b) the aspect of social and cultural interaction of the Chinese Javanese in Chinatown especially in Semarang (c) integration process in Indonesia between Chinese society and local communities do not always running well, could raise barriers, or conflicts between them.

Indonesia is plural society, a society built and united in ethnic groups and turn into a nation in a united Republic of Indonesia. In Indonesian society, there are groups of ethnicities who dominate and being the opposition of the minority in a number of areas in Indonesia both in urban areas and rural areas. The dominant groups are usually the native ethnic who demographically are the majority, and socially they dominate the local political and administrative institutions, and culturally they exercise various symbols, norms and ethics that must be used as the guidance to act in everyday life in public spaces 


\section{Discussion}

\subsection{The Condition and Position of the Chinese Community in Indonesia's Plural Community}

A research revealed that the formation of the Chinese identity is determined by the policy of the ruling government and or a power of a majority community (Dawis, 2010: 38). In other words, the condition of a community in particular area affects and determines the assimilation process.

The Chinese people have long resided in the Indonesian Archipelago, including the city of Semarang, Central Java. They are hybrid Chinese who were born and grew big in Indonesia and has mixed with the local people and culture. They are usually traders. In the colonial era, they managed to enjoy better position compared to the indigenous people or the locals. On the contrary from the independence period up to Old Order, they were marginalized, even in New Order era their movements were frequently hampered except for some special tycoons who were safely protected by the New Order regime. It was only after the Reform that they had gained their freedom (Suryadinata, 2002 and 2010 and Wibowo, 2001 and 2010).

Based on the background, the existence of the Chinese community in Semarang has also gone through many clashes in addressing the identity of their culture. The government policies since the Colonial to New Order era have somewhat forced to comply with the existing regulation. Those regulations in general have given negative impact to their life and identity.

\subsection{Social and Cultural Interaction of the Chinese Javanese in Chinatown}

An identity is shaped through a process of assimilation of the categories between the involved parties, having the ability to minimalize the disparity between the two parties with the help of common consciousness in order to reach togetherness (Wallman, 1983: 70-71). This article raises this question, "Is there common consciousness among the Chinese community in Semarang and the local Javanese to interact through facilities and social and cultural media so that cooperation and positive social and cultural interaction can be developed?

During the fieldwork it was revealed that there has been an interaction of assimilation in the area, especially in Gang Baru Street (Assimilation Market). That place is the oldest market in the Chinatown area in Semarang which until now still serves as interaction media among communities with different faith and culture, but has mutual interest, which is earning a living from the market. Chinatown becomes a sort of vessel for social and cultural amalgamation of diverse communities because it is made up of the Chinese, Arab, Indian, Pakistan, Javanese-descent and other ethnic groups in Indonesia. At the Chinatown an assimilation market develops and it was named 'Gang Baru Assimilation Market'. The market starts at six to eleven am. This Assimilation Market supplies the needs of the Chinatown since colonial era. The visitors who come to this market are not the Chinese living at Chinatown but also other community members.

Other than the traditional market which has been existing many years, there was a media which is deliberately established as new interaction site, and it is called Pasar Semawis 'Semawis Market which is built by Kopi Semawis (Semarang's Chinatown Community for Tourism). This market aims to be the arena for the interaction of the residents of China town and outside to interact for three days in a row, every weekend (Friday to Sunday) at Gang Baru (Baru Alley). Semawis Market unconsciously has continued the tradition already practiced which is Chinese New Year's Eve Market that is held for five days.

Market, products of art and industrial products are the results of the Chinese-Javanese social and cultural interaction which is usually found in Semarang's Chinatown. Another cultural interaction that is easy to find is the culinary world. There are many culinary products which are the results of the adaptation and acculturation between the Chinese-Javanese culture in Semarang's Chinatown, among others are Lumpia' sort of spring rolls' and Lontong Cap Go Meh. These two kinds of food clearly demonstrate the fusion between the needs of food of both the Javanese and Chinese community.

From their historical background the Chinese communities who came to Java Island are relatively cultured than those who came to the other islands. This is caused by the fact that the most part of the immigrants are traders than unskilled workers or labourers. Additionally, their arrival in Java Island was earlier than their fellow immigrant in other islands. In their unconscious communication between the Chinese communities in Indonesia, Chinese and Javanese is regarded as more cultured and grounded compared to the communities in other places who receive negative status and stereotype.

Furthermore, for the Javanese it is easier to accept the Chinese as part of their community when the Chinese is not a trader. The Chinese outside the business sector like in education, law and administration tend to be regarded as more Indonesia than those who involve in business sector. They are regarded as already native or grounded so that they are trustworthy, but those who work in business sector are not accepted as native and have yet grounded (Mahfud, 2013: 42-46). 


\subsection{The Failure of Indonesian Integration Chinese and Local Communities}

In this article the failure of Indonesian integration Chinese and local Communities in Indonesia means a process that is not only targeted to a certain ethnic. As a plural and multicultural society, Indonesia is potentially prone to conflict between the minority and the majority or between the migrants and the locals, or between urban and rural community, or between communities of different faith and culture. Based on that fact, this social and cultural interaction pattern needs to be examined and this kind of study should also about other communities, not just the Chinese community or Chinese ethnic group in Indonesia.

Being Indonesia integration in this case can be seen from an ideal model and empirical model. Ideal model only exists in the aspiration or in hope or can only be found in many state officials' speeches. The empirical model or the everyday life can be found in the social life in many areas in Indonesia. The diversity of the Indonesian people can generally be seen in big cities. In urban areas we would meet with many ethnic groups from all parts of Indonesia. Usually such meeting would take place in public places like markets, stations, terminal, streets, parks, fields, hospitals and schools. The consequence of a culture in such public places is that it would show a culture of general features. Such general culture is also based on the competition among the members of the community that caused an individual or group to seize it using many methods. Indirectly, it is this struggling that has turned into a conflict arena among the community. In such competition an individual or group will utilize and demonstrate symbols as the sign of its power. In this context, the majority usually would suppress the minority because they have more ability to utilize the opportunities in the area.

Despite the fact that the Chinese community is minority, they are strong in their network, both between the Chinese communities in general and between villages or between clans, or between their business interests so that even though they looked different, they have common power when they are suppressed by other parties that threaten their life. By using their networking, they are able to fight back to suppress others because they have direct control over the resources to fight for.

Being Indonesia integration can also be seen from the perspective of their value system that has the ability to blend with the locals or can be seen from the actions and social role in participating and contributing in many fields. What are the Indonesians according to the Chinese? In FGD (focus group discussion with 14 Chinese Javanese in Semarang`s Chinatown in July 2013) it was revealed what Indonesia is all about for them. Firstly, Indonesia is considered as their birth place, particularly for them who were born in Indonesia and their parents have integrated with the Indonesian people. Secondly, Indonesia is considered as the best place to have business and collect wealth as their devotion and worship for the parents and clans. Thirdly, Indonesia for some of them is regarded as just a temporary place. Fourthly, they see Indonesian government before the Reformation has extremely limited their life by regulating their cultural tradition and custom, except for some of them who were protected by the New Order regime. Fifthly, the Indonesian people are regarded as part of the threats in their life in the form of conflict and assault to their life. Sixthly, they are conscious that their existence is still in doubt in the national and state life because they are seen as parasite or as opportunist people by many of the Indonesian people. Seventh, the condition of Indonesia which is not yet so stable, not to mention the changes of the government, has been a traumatic experience in their life. Due to such condition, they become paranoid and extremely cautious in making steps.

Gus Dur's (President Abdurachman Wahid) policy which annulled the Presidential Instruction No.14/1967 was regarded as an opportunity for them to express themselves and at the same time a chance to participate and contribute to social life. However, they still have some doubts and concern to use it, especially in political and bureaucracy aspect. Nevertheless, the opportunities of Reform relating to globalization were fully utilized by the Chinese businessmen by expanding and developing their businesses in many sectors; they even dominate the resources from upstream to downstream. The control over the resources goes beyond the state's control over its resources. This has caused a disparity in welfare between the Chinese community and most of the people. Despite there are some Chinese descent people who are not enjoying the same level of prosperity, they are not significant in number compared to those who have enjoyed privileged lifestyle. It's this gap of welfare that has been one of many obstructions in the interaction between them and the other communities. This really happen and can be found in everyday life of Semarang's Chinatown.

Anthropologist Clifford Geertz once observed that Indonesia's national independence has directly created sentiments of ethno-religious because independence had introduced a sort of "a gift of a very valuable new struggle", which involves the control over the nation. This also applies at very high level in the development of modern capitalist. When operates in such a way to provide equal distribution of its profit to all the existing classifications of culture, the market will have the ability to support the democratic aspiration on civil harmony and civic-related issues. However, when the market processes put the emphasion the wealth and power of one of the ethnic, religious, or cultural segments, it is so likely that they would deteriorate the tensions and destabilize civil accommodations which underpin the welfare for the long 
run. Thus, every attempt to understand the new face of the ethno religious pluralism among the Southeast Asia society (read: Indonesia) should take into account the strong influence of the market making and the nation building over the existing social classification and that would emerge to the surface (Geertz in Hefner, 2007: 22).

In other word, the euphoria after having the freedom in the Reform era and the formation of liberal capitalist market would cause a serious damage to the life of pluralist society like Indonesia. Not to mention that in terms of social and economic aspect, the fact that the Chinese descent Indonesian citizens have stronger position in terms of economic aspect than the Indonesian people who have significantly left behind. This situation has the possibility to trigger new conflict if it is not well accommodated by the government.

Koentjaraningrat, anthropologist, had also talked about this unsynchronized relation between the Chinese and the locals. According to him, Chinese descent had been regarded by part of the Java ethnic groups as an outsider (out-group), and also the other way round, but they put themselves as well as outsider. For example, in the field, business enterprises owned by Chinese ethnic are seen as never entrust high positions in management to non-Chinese professionals. Another example is that mix marriage between Chinese and non-Chinese rarely happened, predominantly between non-Chinese-man with a Chinese-woman. Therefore, both in economic system and in social and cultural system, generally the Chinese ethnic looks separated from the surrounding community (Koentjaraningrat in Habib, 2009:19).

Moreover, there are in fact several other hindrances which have caused the Chinese challenging to interact with the locals. The first explanation might be because there is a disparity in their work ethic, attitude, concern, and trauma caused by their past. There is an impression from the natives that Chinese community in Indonesia are only considered as 'fare-dodger' who only take advantage and anytime can go unnoticed. This impression was, among other, confirmed by the phenomenon in early 2000 when the Chinese descent tycoons run away abroad leaving debt problems to many national and private banks (BLBI case and Century Bank). This negative impression has widened the gap and suspicion of non-Chinese community about the existence of the Chinese people. Not to mention so many drugs smugglers are mostly Chinese who mostly came from Chinese mainland who have yet become Indonesian citizen. News about them always appear every week in the print media and television.

Moreover, there is still a classic obstacle, how they would want to be called. After the Reformation, Chinese descent community did not want to be called Chinese. This has been a prolonged polemic until now. Some of the Chinese community refuse the term but some use it. The reason of their refusal is that the word 'Cina' is felt kind of insult. They prefer to use the word 'Tionghoa', which means those who come from Cun Kwo or the Centre of Central Kingdom which locates in Tiongkok (China). This term 'Tionghoa', according to Parsudi Suparlan, seems to consciously or not wanting to re-establish their legal and social position which was higher than the locals, which was being a foreigner from the East. Therefore, they actually want to place themselves not as Indonesian. Not to mention that traditionally in the life of an ethnic group in Indonesia and in the vocabulary of the ethnic groups in Indonesia the word in their mind is not 'Tionghoa' but 'Cina'. This means Chinese people, through the use of the word 'Cina', have become part of the social life and the life of the ethnic groups in Indonesia, whilst the word 'Tionghoa' is a foreign word which has no context or relevance in the vocabulary of the ethnic groups in Indonesia. It even shows distance with the local communities (see Suparlan, 2006: 46). ${ }^{1}$

Other explanation stated that the word "Cina" (or "China) had been officially uttered, recognized and used both by the concerned community and the international community. The term "Cina", in many cases, has become a concept in everyday language which is realistic among the people. Furthermore, refusing the word "Cina" as a cultural language is exactly the same as doing discriminatory actions, which could become a boomerang for those who only allow themselves to be referred as "Tionghoa" and "not Cina" based on the discriminatory grounds as it is accepted as an insult and humiliating (Tomoidjojo, 2012: 14-15). ${ }^{2}$

\footnotetext{
${ }^{1}$ Tionghoa or Tionghwa is self-made term of the Chinese descent in Indonesia. It originated from a word in Mandarin language, zhonghua, in Hokkian dialect is pronounced as Tionghoa. The discourse of Cung Hwa has started at least in 1880, which was the desire of some people in China to escape the power of the royal dynasty and to establish a more democratic and stronger state. This discourse reached the people from China who resided in Dutch Indies which at that time were named Orang Cina 'Chinese people'. A group of people whose offspring were born in Dutch Indies felt the needs to learn about their culture and language. In 1900 they founded schools in Dutch Indies under the auspices of a body named Tjung Hwa Hwei Kwan which in Indonesia it is pronounced Tiong Hoa Hwe Khan (THHK). In its development THHK didn't just offer language and culture education in Dutch Indies, but also develop a sense of a union among the Tionghoa people in Dutch Indies consistent with the change of the term 'Cina' becoming 'Tionghoa' in Dutch Indies (see Bayu Setia Nugroho, 2011).

2 In her book, Cin Hapsari Tomoidjojo quoted a Letter of Circulation signed on 28 June 1967 by Brigadier General Sudharmono, S.H. acting as the Secretary of the Presidium of Ampera, saying 1) At present time we can still hear the use of the term
} 
Further obstruction is the unhealthy business competition; this has yet been regulated in such a way by the economic and political policies of the government. Moreover, there was an unequal improvement in education in the competition to get knowledge and technology. The impact of such condition would indirectly improve the level of demographic of the middle class Chinese, particularly in urban areas. If the Chinese descent people do not do anything to compensate the condition, it means that they deliberately maintain the unbalanced situation and indirectly let such discrimination to take place. In this regard, despite the awareness of part of the Chinese community who are concerned about the life of being part of a nation and having a homeland, their effort to provide provisional support is likely to only satisfy some of the locals. The concern here is that such provisional and biased policy would only strengthen the stigma of patron, exclusivism, dependency, and educate other community to become beggars.

There is a risk of other obstacles that need to be given attention when the government tries to integrated ethnic heterogeneity into a culture of politics. This is not an easy task; it even can become a boomerang, as happened in the New Order era. This is because ethnic-based loyalty and primordialism could grow stronger when they become a subject of integration, especially when it was carried out coercively or by eliminating their ethnic identities. Such ways can be contra-productive for an integral formation of the culture of politics (Abdilah, 2002: 107 and 201).

For a bad example of the integration forced by the New Order Regime, in one side, with the pressure coming from the New Order government, the Chinese community in Semarang had turned into a militant community in order to keep their faith and culture. They had done it clandestinely yet intensely to pass on their faith and culture to the next generations. In the other side, such pressure had also changed their faith and culture so that some of them had changed their faith and they didn't pay attention to their culture anymore (results interviews in FGD).

Whilst, the first thing is the spirit of Reform. Since the Reform era, politically the opportunities have been opened for many sectors in social life. This was also supported by the Law of the Republic of Indonesia No. 40/2008 on the Elimination of Discrimination of Races and Ethnics. The second part contains of Participation of the Citizens, Article 11, stating that 'Every citizen should participate in the efforts to provide protection and prevention against discrimination of race and ethnic and the ratification of the Citizenship Law. Furthermore, in the era of Gus Dur, the government issued President Decree No.6/2000 on the Repeal of the Presidential Instruction No. 14/1967. With this repeal of the regulation on Religion, Faith and Chinese Custom as a product of New Order regime, Chinese descent in Indonesia were allowed to practice their faith and custom in public. In 2001 President Megawati issued a decree to establish Imlek 'Chinese New Year' as national holiday.

Such condition, directly or indirectly, has encouraged the members of the Chinese descent community to participate in many sectors. This can be seen in their participation in practical political arena which is previously tabooed. Some areas already have Chinese descent Mayor or Regent and in 2014 General Election there is a Chinese descent Vice President-candidate from Hanura Party. This open policy also brings in opportunities for them to voice their rights and aspirations through various media and form a wider business network at local, regional and international level. Another opportunity, particularly at Semarang's Chinatown, is the Perkumpulan Rasa Dharma 'Rasa Dharma Association' and Kopi Semawis, which can be seen as an agency to facilitate the interaction between the Chinese descent and the locals through arts activities and joint market.

Although some obstacles have been cleared, seemingly they haven't fully used such opportunity, particularly in the field of formal politics, like turning into officer and civil or military bureaucrats. The rise of "Ahok" phenomenon (Basuki Tjahyadi as Jakarta's Vice Governor, 2012-2016) ${ }^{3}$ has somewhat encouraged them to enter the field. In our research, the phenomenon was to some extent was probed, but the Chinese community in Semarang's Chinatown seem still in doubt and in a position of waiting for the development.

\footnotetext{
"Tionghoa/Tiongkok" besides the term "Cina" which gradually has developed into a general and official term; 2) From the perspective of ethological-political and etymological-historical, the term "Tionghoa/Tiongkok" contains values that give negative psycho-political association for the Indonesian people, while the term "Cina" in none other than a name of certain dynasty from where the Chinese race comes from, for us those two terms also contain psychological and emotional aspects; 3) Based on the history, it's the term 'Cina' that has long being used and it's that term that is actually acceptable to be used by the Indonesian people in general; 4) Regardless of the emotional and political aspect, it is just natural when we want to use the term "Cina" which has been opted by the Indonesian people; 5) In order to get to the uniformity and effectiveness, and also to avoid dualism in using the term in entire government apparatus, both civil and military, at the Central and Regional, we hope that the term "Cina" can be still used whilst the term "Tionghoa/Tiongkok" is recommended to be left behind, page 284 .

3 Now he has an advanced Governor (2014-2016) after Governor Jokowi, becoming President.
} 


\section{Conclusion}

From historical background and the development social interaction of Semarang's Chinatown as described in prior discussion can be concluded as follows:

1. The long term effect in the social and cultural life has in fact strengthened their identity to stay focus and their orientation should be directed to their ancestor's culture in China. Sooner or later, however, in line with the change of time the younger generation finally realize that they should live among the other ethnics in Indonesia. With that they start to mingle and integrate with the local social and cultural environment, both through trade, friendly relationship, marriage, education and association with the locals. But this movement has yet fully done by the younger generation; most of them who have more resources than the other communities and have higher education than the non-Chinese communities don't show enough care for the life of the nation. This phenomenon shows that they are still just economic animals who focus only on collecting wealth. This is also indirectly affected by their tradition of cultural belief insisting on collecting wealth as much as possible as the proof of their devotion and worship for their parents and clans. Furthermore, this motivation is also affected by the migrant culture that they still hold despite the fact that they have been so long part of the Indonesian people. This negative impression is so attached to the other communities so it has built a gap in their interaction with the locals having different faith and culture and different values.

2. The awakening of their "true" identity relating to their history and tradition emerged in post-New Order and after the Reformation. In that era President Abdurrahman Wahid opened the isolation caused by heavy control over the social and cultural life by eliminating the Presidential Instruction No.14/1967 which has reduced their faith and identity tradition for 32 years,and changes it with the Presidential Decree No. 6/2000. Although opportunities are available, they have yet substantially used in their participation and contribution in improving people's welfare in many fields in the life of being part of a state. In the other side, the government and the community have actually not yet been courageous to open up and give them space or place to participate in the nation development. This external factor is still strong is due to suspicion, prejudice and stereotype of the Indonesian people toward the Chinese. The Chinese people are pragmatic because they are immigrants who have to work hard in order to succeed and have better life than that in the place where they come from. However, this has caused them living separated from the local community due to their improved welfare and it has made them harder to mingle. This is a constraint or obstacle for them to interact with the non-Chinese community and this situation can be seen in this saying on the Chinese from the Javanese, "Cino ya tetep Cino" meaning 'Chinese will be always Chinese'.

3. The interaction between Javanese and Chinese in Semarang's Chinatown has been taken place for so long involving many decades and generations. Chinatown has shown many factors that can provide explanations on the pattern of social and cultural interaction of Javanese and Chinese for centuries, even though there have been changes in power both at local level and at the national level.

4. It is worth emphasizing that of Indonesian integration is not a simple process for them. In one side they have to face constraints of internal hindrances but on the other side they still have to deal with external hindrances, both coming from the government and the majority community in Indonesia. Let alone the fact that becoming Indonesia cannot be forced as the assimilation model in New Order era.

Indonesian integration for the Chinese Javanese especially in Semarang has multi-interpretations and it provides many options or opportunities in the Reform era. In this article, internal hindrances are their weaknesses that they themselves should address. Does the Chinese community have the ability to eliminate or at least minimalize many hindrances facing them? This would so depend on their desire and consciousness in being part of the life of a nation and state.

\section{Acknowledgements}

The research team gives high appreciation to the Directorate of Research and Community Engagement University of Indonesia (DRPM UI) that has provided research funding so that this research can go according to plan and work well. Also the research team provides a great appreciation for the representatives of Chinese community in Semarang on communicative dialogue when FGD in Semarang.

\section{References}

Abdilah, S. U. (2002). Politik Identitas Etnis: Pergaulan Tanda Tanpa Identitas. Yogyakarta: Indonesiatera.

Alkatiri, Z., \& Fabianus, H. K. (2012). Kebersamaan di Ruang Publik pada Pawai Perayaan Gotong Toa Pe Kong Masyarakat Majemuk di Slawi Pasca Orde Baru 2010, Journal Antropologi Indonesia, 2(2), 43-58.

Dawis, A. (2010). Orang Indonesia Tionghoa Mencari Identitas. Jakarta: PT. Gramedia Pustaka Utama. 
Giddens, A., \& Jonathan, T. (ed). (1988). Social Theory Today. California: Stanford University Press.

Graaf, H. J. et al. (1997). Cina Muslim di Jawa Abad XV dan XVI antara Historitas dan Mitos. Yogyakarta: Tiara Wacana Jogya.

Grief, S. W. (1991). WNI: Problematik Orang Indonesia Asal Cina. Jakarta: Grafiti Press.

Habib, A. (2004). Konflik Antaretnik di Pedesaan; Pasang Surut Hubungan Cina-Jawa Yogyakarta: LkiS.

Ham, O. H. (2005). Riwayat Tionghoa Peranakan di Jawa. Depok: Komunitas Bambu.

Ham, O. H. (2008). Anti Cina, Kapitalisme Cina, dan Gerakan Cina: Sejarah Etnis Cina di Indonesia. Depok: Komunitas Bambu.

Hariyono, P. (2004). Kultur Cina dan Jawa: Pemahaman Menuju Asimilasi Kultural. Jakarta: Pustaka Sinar Harapan.

Hefner, R. W. (2007). Politik Multikulturalisme. Jogyakarta: Kanisius.

Joe, L. T. (2004). Riwayat Semarang: Dari Jamannya Sam Poo Sampai Terhapusnya Kongkoan. Semarang: Hasta Wahana.

Koentjaraningrat. (2009). Konflik Antaretnik di Pedesaan: Pasang Surut Hubungan Cina-Jawa. in Achmad Habib. Yogyakarta: LkiS.

Mahfud, C. (2013). Manifestasi Politik Tionghoa di Indonesia. Yogjakarta: Pustaka Pelajar.

Nugroho, B. S. (2011). Meneliti Kehidupan Sosial Budaya Masyarakat Etnis Tionghoa di Wilayah Pecinan: Social Problem: Prasangka, dan Diskriminasi. Hasil Penelitian Program Studi S1 Sosiologi Fakultas Ilmu Sosial dan Ilmu Politik. Universitas Sebelas Maret Surakarta.

Rustopo. (2007). Menjadi Jawa: Orang-orang Tionghoa dan Kebudayaan Jawa di Surakarta 1895-1998. Yogyakarta: Ombak.

Suparlan, P. (2006). Masyarakat Multikultural di Indonesia dan Posisi Orang Cina, Journal Nasion, 3(1), 38-53.

Suryadinata, L. (2002). Negara dan Etnis Tionghoa: Kasus Indonesia. Jakarta: Pustaka LP3ES.

Suryadinata, L. (2010). Etnis Tionghoa dan Nasionalisme Indonesia (Sebuah Bunga Rampai 1965-2008). Jakarta: Kompas.

Svarajati, T. P. (2012). Pecinan Semarang: Dan Dar Der Dor Kota. Semarang: Penerbit Suka Buku.

Thohir, M. (2007). Memahami Kebudayaan Teori, Metodologi, dan Aplikasi. Semarang: Fasindo Press.

Tomoidjojo, C. H. (2012). Jawa-Islam-Cina: Politik Jati Diri Dalam Jawa Safar Cina Sajadah. Jakarta: Wedatama Widya Sastra.

Wallman, S. (1983). Identity Option, in Minorities, Community, and Identity. Berlin: Springer. http://dx.doi.org/10.1007/978-3-642-69311-3_6

Wargatjie, S. N. et al. (2007). Pecinan Semarang: dari Boen Hian Tong sampai Kopi Semawis. Perkumpulan Sosial Rasa Dharma: Semarang.

Wibowo, I. (ed). (2001). Harga yang Harus Dibayar (Sketsa Pergulatan Etnis Cina di Indonesia). Jakarta: PT Gramedia Pustaka Utama.

Wibowo, I, dan T., \& Yu L. (2010). Setelah Air Mata Kering: Masyarakat Tionghoa Pasca Peristiwa Mei 1998. Jakarta: Kompas.

\section{$($ (c)) EY}

This work is licensed under a Creative Commons Attribution 3.0 License. 